\title{
ANALISIS KANDUNGAN SODIUM DAN KLORIDA PADA PENDINGIN PRIMER RSG GAS UNTUK MENGETAHUI KEMURNIANNYA
}

\section{THE SODIUM AND CHLORIDE ANALYSIS IN PRIMARY COOLANT OF RSG GAS TO ANTICIPATE PITTING CORROSION}

\author{
Sriyono \\ Center for Nuclear Reactor Technology and Safety (PTKRN), BATAN, Gedung 80, Kawasan \\ Puspiptek, Serpong, Tangsel, Banten, Indonesia \\ E-mail: sriyono@batan.go.id
}

accepted : Nov 12, 2018 , revised : Nov 15, 2018 , Approved : Nov 23, 2018 )

\begin{abstract}
THE SODIUM AND CHLORIDE ANALYSIS IN PRIMARY COOLANT OF RSG GAS TO ANTICIPATE PITTING CORROSION. The measurement and evaluation of $\mathrm{Na}$ and $\mathrm{Cl}$ content in primary coolant of RSG GAS has been done. Regarding to Safety Analysis Report Rev.10.1 the limit of $\mathrm{Na}$ and $\mathrm{Cl}$ in primary coolant must below than $0.0490 \mathrm{ppm}$, and $0.0115 \mathrm{ppm}$, respectively. The $\mathrm{Na}$ and $\mathrm{Cl}$ predicted initiate pitting corrosion to the reactor tank. RSG GAS reactor vessel is made of $\mathrm{AlMg}_{3}$. At pH of 5.0-7.2 passivation layer established naturally on its surface and protected aluminium from corrosion. When passivation layer was damaged and there was chloride in the coolant will initiate a pitting corrosion. Therefore $\mathrm{Na}$ and $\mathrm{Cl}$ assay in primary coolant have to be done to anticipate pitting corrosion. Three locations water sampling before and after primary coolant purification system was chosen. Those locations are the primary coolant flow before and after KBE01, KBEO2 and FAK01. The Na and Cl content are analyzed by using Atomic Absorption Spectrophotometer (AAS). Based on AAS measurement results, the $\mathrm{Na}$ and $\mathrm{Cl}$ in primary coolant are still in allowable limits. The $\mathrm{pH}$ and conductivity measurement of the year 2005-2016 is also presented in this paper to understand water quality history. The AAS measurement data, $\mathrm{pH}$ and conductivity monitoring showed no trigger or pitting corrosion was detected in the RSG GAS tank.
\end{abstract}

Keywords: sodium, chloride, purity, primary coolant, pitting corrosion, RSG GAS

\section{ABSTRAK}

\begin{abstract}
ANALISIS KANDUNGAN SODIUM DAN KLORIDA PADA PENDINGIN PRIMER RSG GAS UNTUK MENGETAHUI KEMURNIANNYA. Telah dilakukan pengukuran dan analisis kandungan Na dan Cl pada pendingin primer RSG GAS. Unsur Na dan Cl dalam LAK Rev 10.1 dibatasi dibawah 0,0115 ppm dan 0,0490 ppm. Unsur $\mathrm{Na}$ dan $\mathrm{Cl}$ diduga dapat memicu korosi pitting pada tangki RSG GAS. Tangki RSG GAS terbuat dari paduan aluminium ( $\left.\mathrm{AlMg}_{3}\right)$. Pada pH 5,0-7,2 akan terbentuk lapisan pasivasi di permukaan aluminium sehingga terlindungi dari proses korosi. Jika lapisan rusak dan lingkungan mengandung klorida maka memicu korosi
\end{abstract}


pitting. Oleh karena itu penyebab korosi pitting harus diamati dan diantisipasi. Tujuan penelitian ini adalah melakukan pengukuran dan analisis konsentrasi kandungan $\mathrm{Na}$ dan $\mathrm{Cl}$ pada pendingin primer untuk mengetahui kemurniannya sehingga korosi pitting tidak terjadi. Metodologi yang digunakan adalah pengukuran sampel air primer dengan AAS pada 3 lokasi sampling baik sebelum maupun sesudah sistem purifikasi pendingin primer. Lokasi tersebut adalah aliran pendingin primer sebelum dan sesuadah KBE01, KBE02 dan FAK01. Berdasarkan hasil pengukuran dengan AAS diketahui bahwa unsur $\mathrm{Na}$ dan $\mathrm{Cl}$ pada pendingin primer masih dalam batas yang diijinkan. Hasil pengukuran $\mathrm{pH}$ dan konduktivitas air primer juga ditampilkan di makalah ini untuk mengetahui sejarah kemurnian air. Data pengukuran AAS, monitoring $\mathrm{pH}$ dan konduktivitas menunjukkan tidak terdeteksi adanya pemicu ataupun korosi pitting pada tangki RSG GAS.

Kata kunci: sodium, klorida, korosi pitting, aluminium, RSG GAS

\section{INTRODUCTION}

The Reaktor Serbaguna GA pool-type research reactor, which has been constructed in Serpong area since 1983. The reactor reached first criticality on July $1987^{[1]}$ and achieved maximum power of $30 \mathrm{MW}$ on March 1992. The RSG-GAS has an average neutron flux of $10^{14} \mathrm{n} / \mathrm{cm}^{2} . s$ which results from fission reaction in its core. The RSG-GAS has $\mathrm{U}_{3} \mathrm{O}_{8} \mathrm{Al} / \mathrm{U}_{3} \mathrm{Si}_{2} \mathrm{Al}$ fuel with $19.75 \%$ uranium enrichment ${ }^{[2,3]}$.

There are primary and secondary coolant in RSG-GAS. Both of these systems ensure that the reactor coolant temperature is controlled and safe ${ }^{[3,4]}$. During normal operation, heat is generated in the core and taken by primary cooling system and transfers the heat from reactor core to the secondary cooling system via heat exchangers. The heat is discharged into the environment through cooling towers by forced circulation.

The reactor coolant must be managed to meet their specifications ${ }^{[4]}$. The controlling method for both primary and secondary coolant are monitoring of $\mathrm{pH}$, conductivity, and TDS (total dissolved solids). The water sampling is also conducted to determine any impurities i.e. $\mathrm{Cl}, \mathrm{Mg}, \mathrm{SO}_{4}, \mathrm{Na}$, etc.

The mechanical and chemical treatment is conducted in the cooling system to meet allowable limit requirements. In the primary cooling system, water is continuously passed through purification systems that consist of a mechanical filter and ion exchange resin bed. RSG GAS has 3 purification systems i.e. KBE01 system (primary pool purification system), KBE02 system (warm water layer purification system) and FAK01 (spent fuel storage purification system). In the secondary cooling system, the chemical additives are used to suppress corrosion, as an anti-crust and to suppress the moss/microorganisms growth ${ }^{[5]}$.

The primary cooling system plays an important role to maintain the integrity and reliability of reactor structures, systems and components (SSCs). Aluminum has an excellent resistance to corrosion; therefore it is used for the reactor tank and other primary 
component material ${ }^{[6,7]}$. In the $\mathrm{pH}$ of 5.0 7.2 , the passivation layer is naturally established on aluminum surface, and protects the aluminum from corrosion ${ }^{[8]}$. As a function of time, the mechanical process will damage the surface and destruct the passivation layer ${ }^{[9,10]}$. The damage of passivation layer is caused by the poor water management which could generate pitting corrosion. The pitting corrosion must be avoided in the primary system because it can make a primary water leakage to the concrete and surrounding environment.

Pitting corrosion, simply called pitting, is a form of extremely localized corrosion that leads to the creation of small holes in the metal. The driving force for pitting corrosion is the depassivation of a small area, which becomes anodic while an unknown but potentially extensive area becomes cathodic, leading to very localized galvanic corrosion ${ }^{[11]}$. The corrosion penetrates the mass of the metal through intrusion of limited ion diffusion. Pitting can be initiated by a small surface defect, which change material composition and damage the protective coating. The pitting corrosion creates small hole in the tank and make a leakage ${ }^{[12]}$. In addition to surface defects, pitting corrosion is caused by the presence of Sodium and Chlorine ion $(\mathrm{Cl})$ as well ${ }^{[13,14]}$. Therefore, in order to anticipate pitting corrosion which caused by chlorine ion $(\mathrm{Cl})$ and sodium $(\mathrm{Na})$ the primary cooling monitoring of RSG GAS is required.

This paper discusses the analysis of $\mathrm{Na}$ and $\mathrm{Cl}$ trace elements measurement in the primary coolant of RSG GAS. The research objective is to determine the amount of $\mathrm{Na}$ and $\mathrm{Cl}$ in the primary coolant to prevent pitting corrosion that may occur in the reactor tank. The research methodology used is water sampling at 3 locations before and after of purification system of primary coolant. The primary water impurities measurement is done by using Atomic Absorption Spectrophotometer (AAS). This measurement is expected to be able to minimize the possibility of pitting corrosion due to the presence of $\mathrm{Na}$ and $\mathrm{Cl}$ in the primary coolant of RSG GAS. The $\mathrm{pH}$ and conductivity measurement of the year 2005-2016 is also presented in this paper to understand water quality history. Both of those parameters should be monitored during whole life of RSG GAS.

\section{THEORY}

\section{a. Primary Coolant of RSG GAS}

The RSG-GAS has two main loops of cooling system which are shown in Figure $1^{[1,2]}$. The water role as moderator and radiation shielding in axial direction. The primary coolant uses demineralized water which is produced from GCA01 (the demineralized water production system). The primary loop consists of reactor pool and all the connected system, including reactor vessel, primary piping, and heat exchanger. The entire components are filled by demineralized water from GCA01 ${ }^{[5]}$. The secondary coolant system uses tap water. The primary coolant purification system is shown in Figure $1^{[1]}$.

The primary coolant has $330 \mathrm{~m}^{3}$ volume of demineralized water, including $220 \mathrm{~m}^{3}$ in the reactor pool, $80 \mathrm{~m}^{3}$ in the delay chamber and $30 \mathrm{~m}^{3}$ in the primary piping system. The $\mathrm{pH}$ and conductivity of demineralized water is monitored and measured before it is stored to the storage tank BB04. If $\mathrm{pH}$ and conductivity did not meet the specification, the reflushing is done. Table 1 shows demineralized water specification ${ }^{[1,2]}$. 
Table 1. The demineralized water specification of RSG GAS ${ }^{[1,2]}$

\begin{tabular}{|l|c|}
\hline \hline \multicolumn{1}{c}{ Parameter } & \multicolumn{1}{c}{ Limit Value } \\
\hline \hline $\mathrm{pH}$ & $6.5-7.5$ \\
\hline Conductivity (max) & $2 \mu \mathrm{S} / \mathrm{cm}$ \\
\hline Chloride ion (max) & $0.094 \mathrm{ppm}$ \\
\hline Copper ion (max) & $0.056 \mathrm{ppm}$ \\
\hline $\mathrm{SO}_{4}{ }^{2-}$ & $<0.0528 \mathrm{ppm}$ \\
\hline $\mathrm{Al}^{+3}$ & $<0.0103 \mathrm{ppm}$ \\
\hline $\mathrm{Na}^{+}$ & $<0.0115 \mathrm{ppm}$ \\
\hline \hline
\end{tabular}

b. Pitting Corrosion and Mechanisms

The pitting corrosion is an autocatalytic process. Metal oxidation results in localized acidity that is maintained by the spatial separation of the cathodic and anodic half-reactions, which creates a potential gradient and electro migration of aggressive anions into the pit ${ }^{[13]}$. For example, if a metal is in an oxygenated $\mathrm{NaCl}$ electrolyte, the pit acts as anode and the metal surface acts as cathode. The localized production of positive metal ions in the pit gives a local excess of positive charge which attracts the negative chlorine ions from the electrolyte to produce charge neutrality.

The pit contains a high concentration of $\mathrm{M}-\mathrm{Cl}$ molecules which react with water to produce $\mathrm{HCl}$, the metal hydroxide, and $\mathrm{H}^{+}$ions, accelerating the corrosion process. In the pit, the oxygen concentration is essentially zero and all of the cathodic oxygen reactions take place on the metal surface outside the pit. The pit is anodic and the locus of rapid dissolution of the metal ${ }^{[13]}$. The metal corrosion initiation is autocatalytic in nature however its propagation is not. This kind of corrosion is extremely insidious, as it causes little loss of material with the small effect on its surface, while it damages the deep structures of the metal. The pits on the surface are often obscured by corrosion products.

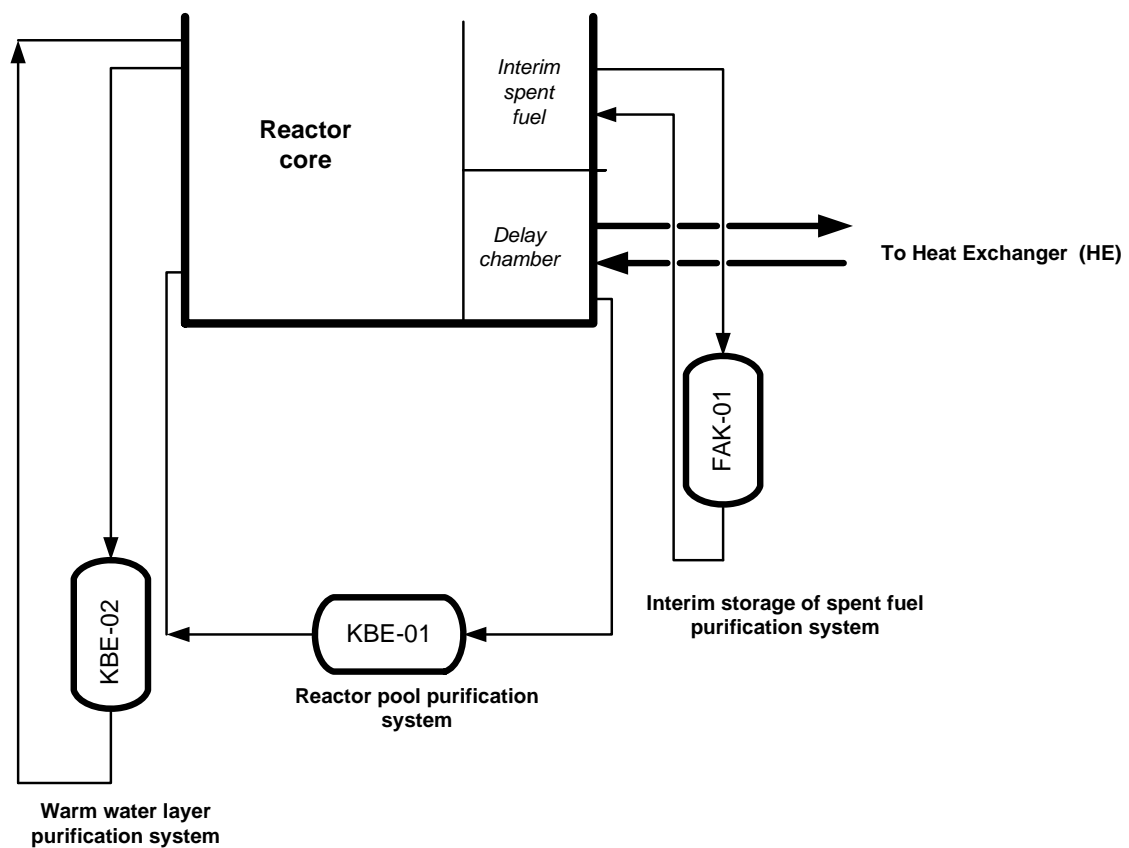

Figure 1. The Purification System of Primary Coolant of RSG GAS ${ }^{[1,2]}$. 


\section{METHODOLOGY}

This research was done by several sampling at primary coolant and its analysis using by AAS. The AAS laboratory equipment is supported by Center for Radioactive Waste Technology (PTLR). There are 3 locations are decided i.e. before and after the reactor pool cooling water purification system (KBE01), reactor warm water layer purification system (KBE02), interim spent fuel storage purification system (FAK01) sampling points.

AAS is a quantitative analysis technique that use in very broad application and in many fields. This tool has selective procedures, relatively cheap cost analysis, high sensitivity (ppm to $\mathrm{ppb}$ ), and can be done quickly. AAS is generally used to analyze the content of the elements in the solution ${ }^{[15]}$. The basic principle of AAS states that atoms absorb specific wavelengths of electromagnetic radiation. Spectro photometry is a technique used in measuring the quantity of light absorbed by a substance ${ }^{[16]}$. Spectrophotometry is a useful tool in quantitative analysis where the concentration of a substance is to be identified. AAS assays the metal content in water. Firstly, the molecules in the solution undergo atomization to free the atoms from their bonds with other elements. The main components of an AAS are a light source, atomizer, monochrometer and a detector. The principle of AAS measurement is shown in Figure 2.

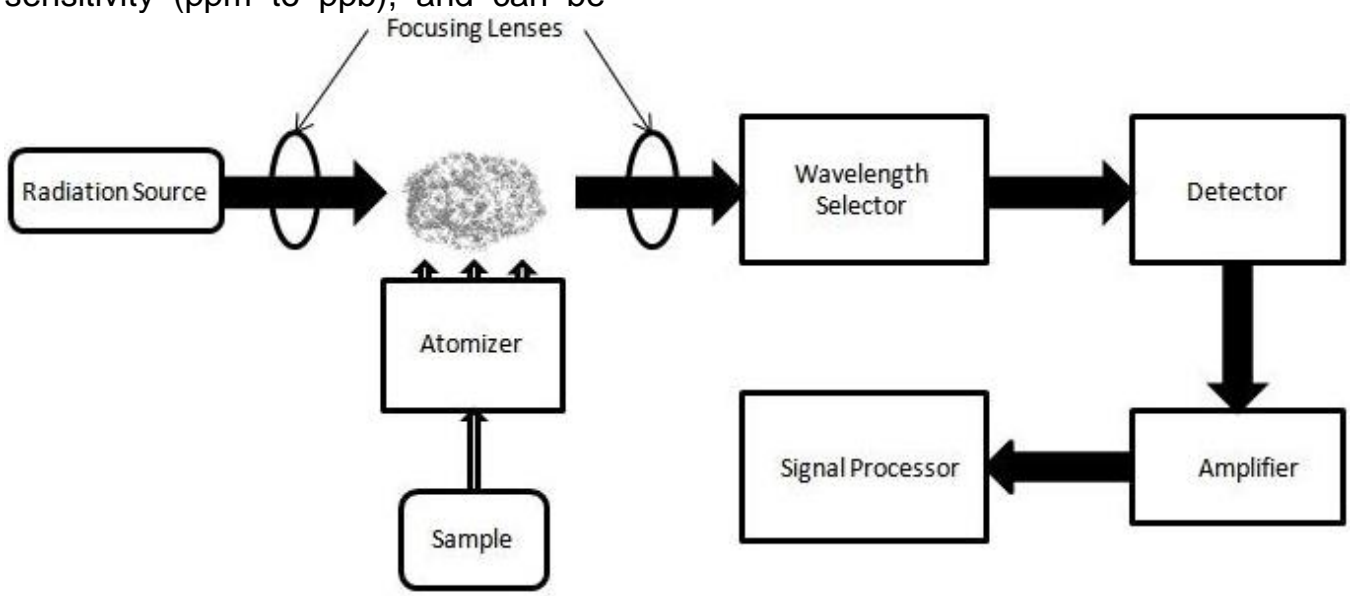

Figure 2. The AAS measurement principle [17]

flame. This conditioning process is

Liquid or dissolved samples are typically used with flame atomizers. The sample solution is aspirated by a pneumatic analytical nebulizer transformed into an aerosol, which is introduced into a spray chamber, where it is mixed with the flame gases and conditioned in a way that only the finest aerosol droplets $(<10 \mu \mathrm{m})$ enter the responsible that only about $5 \%$ of the aspirated sample solution reaches the flame, but it also guarantees a relatively high freedom from interference. On top of the spray chamber, there is a burner head that produces a laterally long flame (usually $5-10 \mathrm{~cm}$ ) and only a few $\mathrm{mm}$ deep. The radiation beam passes through this flame at its longest axis, and the flame gas flowrates may be adjusted 
to produce the highest concentration of free atoms. The burner height may also be adjusted, thus the radiation beam passes through the zone of highest atom cloud density in the flame, resulting in the highest sensitivity. The processes in a flame include the stages of desolvation (drying) in which the solvent is evaporated and the dry sample, nano particles remain, vaporization in which the solid particles are converted in to gaseous molecule; atomization in which the molecules are dissociated into free atoms; and ionization where atoms may be partly converted to gaseous ions. as follow:

The AAS measurement steps are

1. $1000 \mathrm{ml}$ of sample water from KBE01, KBE02, and FAK01 was prepared

2. The water sample then counted to ensure that the emitted radiation exposure does not exceed the threshold dose required of 10 mRem.

3. Water sample is prepared in ampoules to be analyzed of $\mathrm{Na}, \mathrm{Cl}$, etc. by AAS

4. $\mathrm{Na}$ and $\mathrm{Cl}$ standard solutions are prepared by suitable dilution, with deionized water, of the stock standard solution described under the Standard Conditions for Sodium and Chloride.

5. The measurement is conducted and the result recorded to every water sample

\section{RESULT AND DISCUSSION}

The primary coolant plays important role in maintaining the reliability of structures, systems, and components (SSC) of RSG GAS. The primary coolant quality is maintained by continuously pass it through purification system which includes mechanical filter and anion/cation resin column. The $\mathrm{pH}$ and conductivity are monitored once a week. The conductivity monitoring in the primary coolant during the the year of 2005 to 2016 is shown in Figure 3, which is never exceeded the SAR requirement. It indicates that the primary coolant management has been implemented correctly and properly in accordance with standard and operating procedure (SOP).

Conductivity is an indicator of water's capability to pass the electrical flow. It has a direct relation to the concentration of ions in the water. These conductive ions come from dissolved salts and inorganic materials such as alkalis, chlorides, sulfides and carbonate compounds. Compounds that dissolve into ions are also known as electrolytes. The more ions present, the higher conductivity of water. In reverse, the fewer ions present in water, the less conductive of it. Distilled or demineralized water can act as an insulator due to its very low (if not negligible) conductivity value. It means that the primary coolant water is clean and gives in significant effect to the reactor tank corrosion.

It can be concluded that the amount of electrolyte ions are in the primary cooling water below the requirements in Safety Analysis Report thus the triggers of corrosion can be avoided.

RSG GAS primary cooling uses very low conductivity of demineralized water. The existing ions bounded by resin during purification process. Refer to the Safety Analysis Report (SAR) Rev.10.1; the limit of conductivity must below of $8.0 \mu \mathrm{S} / \mathrm{cm}$.

The Reactor Operation Report (2005-2016) shows that minimum average conductivity values are around $1.02 \mu \mathrm{S} / \mathrm{cm}$ and average maximum values are $1.52 \mu \mathrm{S} / \mathrm{cm}$. This value indicates that primary water reactor is well maintained. Low conductivity means very low dissolved ions. The corrosion 
that will occur in the reactor tank and SSC of RSG GAS can be prevented.

The $56^{\text {th }}$ Operation Cycle Report (March 2006) indicated the anomaly value of conductivity at $9 \mu \mathrm{S} / \mathrm{cm}$. The conductivity increase was caused by debris from Be (Beryllium) reflector gap released to the primary coolant (KBE01). The debris established during $\mathrm{Be}$ reflector inversion [17]. Several steps has been carried out to repurify the primary cooling water, i.e. replacing the coolant by fresh demineralized water, replacing the resin at KBE01, KBE02, and FAK01 resin column. After the replacing process of those resins conductivity returns to the desire level of $2.0 \mu \mathrm{S} / \mathrm{cm}$. The $\mathrm{pH}$ monitoring since 2005 is seen in Figure 4. The $\mathrm{pH}$ indicates acidity or alkalinity solution. The $\mathrm{pH}$ environment affects the types of corrosion reactions. In environments with high acidity (low $\mathrm{pH}$ ), corrosion will take place with the hydrogen evolution reaction on its cathodic area. The replacement ion exchange resin in purification column ensures that water quality is achieved. The replacement is based on the pressure drop between inlet and outlet of resin bed, the radiation exposure measurement level from the resin column, $\mathrm{pH}$ and conductivity value. Several instrumentations were installed close to the system to measure every parameter of water. The measurement value can be seen in Main Control Room (MCR). The operation log book is used to data recording continuously. The sampling line is available to daily or weekly of $\mathrm{pH}$ and conductivity monitoring.

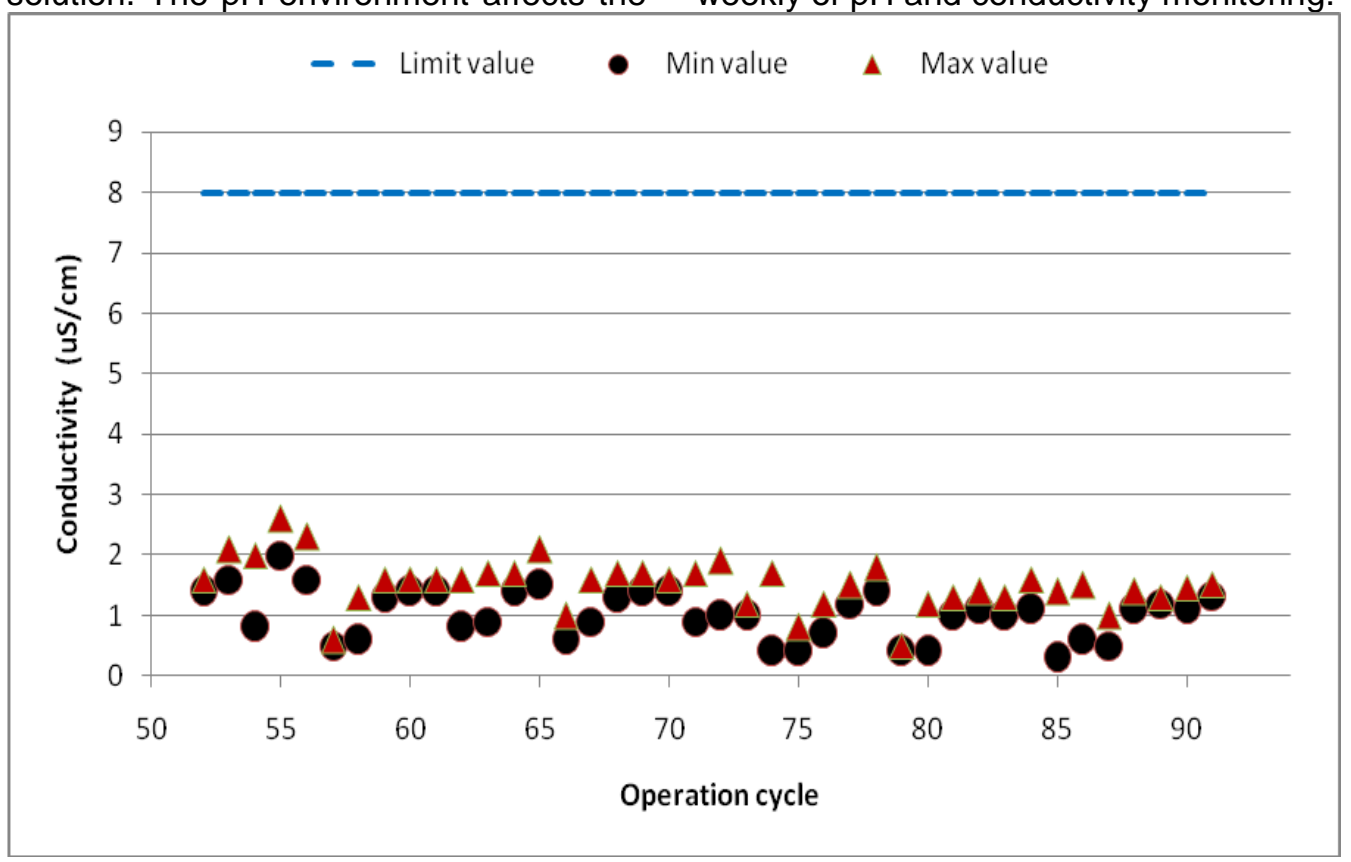

Figure 3. The Primary Coolant Conductivity Monitoring Results During 20052016 




Figure 4. pH Monitoring of Primary Coolant During 2005-2016 of RSG GAS Operation

The TDS monitoring during 20112016 of RSG GAS operation has been reported in the range of $0.2-1.5 \mathrm{mg} / \mathrm{l}$ [15]. Total dissolved solids (TDS) is a measure of the combined content of all inorganic and organic substances contained in a liquid in molecular, ionized or micro-granular (colloidal sol) suspended form. The primary coolant TDS value is still below the primary coolant requirements limit and it clearly indicated that primary water in a good condition regarding to safety.

The existing of Sodium $(\mathrm{Na})$ and Chloride $(\mathrm{Cl})$ affected to the reactor tank corrosion. Corrosion that may occur is pitting corrosion. The reactor tank material is made of $\mathrm{AlMg}_{3}$. In the $\mathrm{pH}$ of 5.0-8.0 the alluminium oxide $\mathrm{Al}_{2} \mathrm{O}_{3}$ layer is established. This layer will be a passivation layer and protects to corrosion [18,19]. The AAS analysis result from the primary water of RSG GAS is shown in Table 2.

Table 2. The $\mathrm{Na}$ and $\mathrm{CI}$ Measurement Results of RSG GAS Primary Coolant

\begin{tabular}{|c|c|c|c|c|c|}
\hline Location & $\begin{array}{c}\text { No of } \\
\text { Water } \\
\text { Sample }\end{array}$ & $\mathrm{pH}$ & $\begin{array}{l}\text { Conductivity } \\
(\mu \mathrm{S} / \mathrm{cm})\end{array}$ & $\begin{array}{c}\text { Sodium } \\
\text { (Na) } \\
\text { (ppm) }\end{array}$ & $\begin{array}{c}\mathrm{Cl} \\
(\mathrm{ppm})\end{array}$ \\
\hline \multirow{3}{*}{$\begin{array}{l}\text { KBE01 (inlet } \\
\text { flow of KBE01 } \\
\text { resin bed) }\end{array}$} & 1 & 5.8 & 2.4 & 0.031 & 0.011 \\
\hline & 2 & 6.0 & 2.6 & 0.032 & 0.01 \\
\hline & 3 & 5.8 & 2.4 & 0.032 & 0.011 \\
\hline \multirow{3}{*}{$\begin{array}{l}\text { KBE01 (outlet } \\
\text { flow of KBE01 } \\
\text { resin bed) }\end{array}$} & 1 & 6.5 & 3.0 & 0.021 & 0.009 \\
\hline & 2 & 6.6 & 2.8 & 0.021 & 0.008 \\
\hline & 3 & 6.6 & 3.1 & 0.022 & 0.008 \\
\hline KBE02 (inlet & 1 & 6.0 & 2.8 & 0.040 & 0.011 \\
\hline
\end{tabular}




\begin{tabular}{lccccc}
\hline flow of KBE02 & 2 & 6.0 & 2.6 & 0.042 & 0.012 \\
\cline { 2 - 6 } resin bed) & 3 & 6.2 & 2.5 & 0.041 & 0.011 \\
\hline KBE02 (outlet & 1 & 6.8 & 2.2 & 0.026 & 0.009 \\
\cline { 2 - 6 } flow of KBE02 & 2 & 6.5 & 2.4 & 0.028 & 0.008 \\
\cline { 2 - 6 } resin bed) & 3 & 6.6 & 2.2 & 0.027 & 0.010 \\
\hline FAK01 (inlet & 1 & 5.8 & 3.2 & 0.032 & 0.011 \\
\cline { 2 - 6 } flow of FAK01 & 2 & 6.0 & 3.2 & 0.03 & 0.011 \\
\cline { 2 - 6 } resin bed) & 3 & 5.8 & 3.4 & 0.032 & 0.011 \\
\hline FAK01 (outlet & 1 & 6.8 & 3.0 & 0.024 & 0.011 \\
flow of FAK01 & 2 & 6.5 & 2.8 & 0.022 & 0.01 \\
resin bed) & 3 & 6.6 & 2.9 & 0.022 & 0.009 \\
\hline GC01 & 1 & 6.8 & 1.9 & 0.007 & 0.010 \\
(demineralized & 2 & 6.8 & 1.8 & 0.008 & 0.008 \\
\cline { 2 - 6 } water tank) & 3 & 6.8 & 1.8 & 0.006 & 0.010 \\
\hline
\end{tabular}

Based on Table 2, the $\mathrm{Na}$ and $\mathrm{Cl}$ measurement results of primary water are still within the allowable specification range. The $\mathrm{Na}$ concentration in the inlet of KBE01 is higher than the specification limit but it decreases significantly after purification process. Water samples were taken based on $91^{\text {st }}$ reactor operation cycle in the last of 2016. All of resin column in the purification system (KBE01. KBE02 and FAK01) indicate a good performance. The concentration of sodium and chlorine elements in primary coolant is below the allowable limit. The pitting corrosion can be anticipated. In general, the stage of pitting corrosion is initiated by adsorption of chloride ions on the surface of the oxide layer then the penetration of chloride ions in the oxide layer and the last is a chloride leaching below the surface of the metal oxide layer and essentially ${ }^{[20,21]}$. Sodium is not corrosive substance. Most of aluminum material is highly resist to $\mathrm{Na}{ }^{[22]}$. Sodium is easy to interacts with $\mathrm{Cl}$ formed $\mathrm{NaCl}$ (sodium chloride). In the high temperature environment with excess of $\mathrm{Na}$. sodium to interact with $\mathrm{H}_{2} \mathrm{O}$ to form $\mathrm{NaOH}$ such in Sodium Cooled Reactor (SCR). The high concentration of $\mathrm{NaOH}$ will increase the alkalinity of cooling system and accelerate the corrosion process.

Refer to the RSG GAS SAR (Safety Analysis Report) Rev 10.1., the sodium (Na) concentration must be below 0.0115 ppm. Refering to Table 2, it is shown that at 3 locations are measured. Na does not exceed the specified conditions.

By good primary water management it can prevent corrosion. The reliability of reactor SSCs can be maintained by controlling of $\mathrm{pH}$, conductivity, TDS and several elements such as sodium and chloride. It is explained also in the research that has been done by Elisabeth Ratnawati et.el. [23]. Cathodic or anodic protection to avoid corrosion cannot be done because the wide spread area of the primary component/piping. The inhibitors addition to the primary coolant is not possible because of its neutron interaction to the inhibitors and makes any new impurities.

\section{CONCLUSION}

Based on AAS measurement results, the $\mathrm{Na}$ and $\mathrm{Cl}$ in primary coolant are still in allowable limits. The conductivity and $\mathrm{pH}$ monitoring based on reactor operation report of the year of 2005-2016 are never exceeded. The 
AAS measurement data, $\mathrm{pH}$ and conductivity monitoring showed no trigger or pitting corrosion was detected in the RSG GAS tank. It can be predicted that there was no corrosion problem in the primary system of the RSG GAS. The pitting corrosion can be avoided by a good water management.

\section{ACKNOWLEDGEMENTS}

The author would like to appreciate thank staff of Center for Multipurpose Reactor (PRSG) for their help and support during this research and also Center for Radwaste Management in AAS analysis. The author also appreciates thank you very much to PTKRN on financial support through DIPA Fiscal Year of 2016 and 2017.

\section{REFERENCES}

[1]. Batan-RSG-GAS, "Multipurpose Reactor GA Siwabessy Safety Analysis Report Rev.10.1“, Vol. 1. Copy No.1, PRSG-BATAN, Indonesia, 2011

[2]. Geni Rina Sunaryo, Sriyono, Diyah Erlina, "Water Chemistry Surveillance for Multipurpose Reactor 30 MW GA Siwabessy, Indonesia", Proceeding International Conference on Research Reactors: Safe Management and Effective Utilization, Sydney, Australia, 5-9 November 2007, pp 56-61.

[3]. Sriyono, Rahayu K, Abdul Hafid, Sofia Loren B, Geni Rina Sunaryo, Dyah E.L. Elisabeth R, "The Debris Particles Analysis of RSG-GAS Coolant to Anticipate Sediment Induced Corrosion", Jurnal Pengembangan Energi Nuklir, Volume 19, Nomor 2, Juni 2016, ISSN 1410-9816, 2016, pp 11-21
[4]. Geni Rina Sunaryo, Sriyono, "Surveillance Corrosion for Interim Storage", Prosiding Seminar Nasional Energi Nuklir (SENTEN) 2016, ISSN: 2355-7524, PTKRN BATAN, 2016, pp 617-624

[5]. Sriyono, Rahayu K., Sugiyanto, Diyah EL., "Analysis of Topaz Irradiation Effect To The Existing of Co-60 in RSG GAS Primary Coolant", Prosiding Seminar Nasional Energi Nuklir (SENTEN) 2016, ISSN: 2355-7524, PTKRN BATAN, 2016, pp 641-648

[6]. IAEA, Trs 418, "Corrosion of Research Reactor Aluminum Clad Spent Fuel in Water", IAEA, Vienna, Austria, 2008.

[7]. Haddadd R., et.al.,"Evaluation of Aluminium Clad Spent Fuel Corrosion in Argentine Basins", Corrosion Materials, CNEA, Argentina, 2015, pp 79-85

[8]. Ramanathan LV, Haddad RE, et.al., "Corrosion of Spent Fuel Aluminium Clad Reserach Reactor Fuel-synergism in the Role of Storage Basin Water Parameters", Corrosion Materials, CNEA, Argentina, 2014, pp 25-30

[9]. Aziz P.M., Godard, H.P., Pitting Corrosion Characteristics of Aluminium, Journal of Industrial Engineering and Chemistry, vol. 44, 2012, pp 8-16

[10]. Bhandari Jyoti, Faisal Khan, et.al., "Modeling of Pitting Corrosion in Marine Offshore Steel Structures-A Technical Review“, Journal of Loss Prevention in the Process Industries 37, 2015, pp 39-62.

[11]. VS Raja, Bharat S, Padekar, "Role of Chlorides on Pitting and Hydrogen Embrittlement of Mg-Mn Wrought Alloy“, Corrosion Science, Vol. 75, October 2013, pp 176183. 
[12]. Dian Anggraeni, Diyah EL., S. Budi U.. "Analisis Korosi Paduan $\mathrm{AlMg}_{2}$ dan AIMgSi Menggunakan Metode Elektrokimia", Jurnal Urania Vol 20, No. 3. Oktober 2014, pp 33-39

[13]. Tuthil Arthur, Richard E. Every, et.al., "Effect of Chlorine on Common Materials in Fresh Water", Materials Science of Journal, 2014, pp 15-20

[14]. Elisabeth R., Diyah E.L., Setyo Budi, "Pengaruh Irradiasi Batu Topaz Terhadap Kualitas Air Pendingin Reaktor GA Siwabessy“, Prosiding Seminar Nasional Teknologi Dan Aplikasi Reaktor Nuklir ISBN 976-97917109-7-8, Indonesia, 2012, pp 37-46

[15]. PRSG, "Laporan Operasi Reaktor RSG GAS Periode 2005-2016", Bidang Operasi Reaktor, Pusat Reaktor Serba Guna, 2005-2016

[16]. Supriatno, Lelifajri, "Analisis Logam Berat $\mathrm{Pb}$ dan $\mathrm{Cu}$ Dalam Sampel Ikan dan Kerang Dengan Spekrometri Serapan Atom", Jurnal Rekayasa Kimia dan Lingkungan Vol. 7. No. 1. ISSN 1412-5064, 2014. hal. 5-8.

[17]. PRSG, "Laporan Umpan Balik Pengalaman Operasi : Kejadian Konduktivitas Air Primer Naik Hingga > $8 \mu \mathrm{S} / \mathrm{cm}$ ", Pusat Reaktor Serba Guna, 2006

[18]. R. Arrabal, M. Mingo.et.al., "Pitting Corrosion of Rheocast A356 Aluminium Alloy in 3.5 wt\% $\mathrm{NaCl}$
Solution", Corrosion Science, Vol. 73, August 2013, pp 342-355.

[19]. Kim. Y.S., Hofman. G.L., Robinson. A.B., Snelgrove. J.L., Hanan. N., "Oxidation of Aluminum Alloy Cladding for Research and Test Reactor Fuel“, Journal of Nuclear Material, 378, 2013, pp 220-228.

[20]. MC.Cafferty E., "Sequence of steps in Pitting of Alluminum by Chloride Ions", Corrsion Science 45, 2013, pp1421-1438.

[21]. W. Qafsaoui. M.W. Kendig. H. Perrot. H. Takenouti, "Effect of 1Pyrolydine diethiocarbamate on Galvanic Coupling Resistance of Intermetalics- Aluminium Matrix during Corrosion of AA 2024-T3 in a Dilute $\mathrm{NaCl}$ ", Corrosion Science, Volume 92, March 2015, pp 245255.

[22]. Manish Gupta, Jyotsna Mishra, KS Pitre, "Corrosion and Inhibition Behavior of Aluminium in Alkaline Medium and Sodium Silicate", International Journal of Advancements in Research \& Technology, Volume 3, Issue 7, July 2014, ISSN 2278-7763, pp 112-119

[23]. Elisabeth Ratnawati, Diyah Erlina Lestari, Th. Rina Mulyaningsih, "Studi Pengotor pada Pendingin Primer Reaktor RSG GAS Setelah 30 Tahun Beroperasi”, Jurnal Iptek Nuklir Ganendra, Vol. 21 No. 1, Januari 2018, pp 17-24 